John Carroll University

Carroll Collected

2019 Faculty Bibliography

Faculty Bibliographies Community Homepage

2019

\title{
Portfolio Society: On the Capitalist Mode of Prediction
}

Mindy Peden

John Carroll University, mpeden@jcu.edu

Follow this and additional works at: https://collected.jcu.edu/fac_bib_2019

Part of the Political Science Commons

\section{Recommended Citation}

Peden, Mindy, "Portfolio Society: On the Capitalist Mode of Prediction" (2019). 2019 Faculty Bibliography. 3.

https://collected.jcu.edu/fac_bib_2019/3

This Book Review is brought to you for free and open access by the Faculty Bibliographies Community Homepage at Carroll Collected. It has been accepted for inclusion in 2019 Faculty Bibliography by an authorized administrator of Carroll Collected. For more information, please contact connell@jcu.edu. 
Portfolio Society: On the Capitalist Mode of Prediction, by Ivan Ascher, New York, Zone Books, 2016, 191 pp., \$25.95 (hardcover), ISBN: 9781935408741

How do we make sense of the influence that financial markets have on the world today? In his slim and mighty volume, Ivan Ascher invokes and develops Karl Marx's critical approach to political economy to help us understand the brave new world of capitalism that is shrouded in mystery and that asserts itself as natural, with explanation only through reference to the supernatural. Portfolio Society: On the Capitalist Mode of Prediction is full of surprising insight and stays faithful to Marx's historical materialism by helping us to see contemporary machinations of alienation, dead labor, and the continued relevance of class analysis. Where production is the central verb for Marx's project, for Ascher it is prediction.

To understand the centrality of prediction, Ascher turns to Harry Markowitz's theory of portfolio management which recommends, among other things, diversification of holdings to reduce the overall risk of the portfolio. This approach helps explain the rise of securitization, which Ascher describes as:

\footnotetext{
${ }^{3}$ J.N. Figgis, Churches in the Modern State (London, UK: Longmans, Green and Co., 1914), p. 88.

${ }^{4}$ Tim Rogan, "Why Amartya Sen Remains the Century's Great Critic of Capitalism," Aeon (February 27, 2018), available at: https://aeon.co/ideas/why-amartya-sen-remains-the-centurys-great-critic-of-capitalism.
} 
the peculiar mechanism whereby a lender is not only able to lay claim to future value, but also merely by virtue of holding a portfolio of securities, to borrow money on the financial markets more cheaply than she has lent it. (p. 71)

While Marx saw profit as the appropriation of surplus value from productive labor, the contemporary investor's expropriation happens through the practices of borrowing and lending money. One's economic class position (over)determines one's interest rates, so that in one class money is made without any tangible product and literally by borrowing money that is then lent at a higher interest rate to the most desperate, thereby fueling contemporary economic inequality. Several themes emerge as the chapters unfold, and Ascher deftly guides the reader through discussions about pricing, the meaning of Beta, the very absurdity of hedging on future value, and ultimately the particular mode of prediction characteristic of the enormously powerful financial sector that now confronts and transforms the modern subject, often understood as both natural and objective.

One such modern subject is the investor, the holder of a portfolio which is in turn made up of investments held by others. As Ascher points out, however, "investors in a synthetic CDO do not all share the same interest, in other words, and they certainly do not all share the same interest as the borrowers (or as the manager of a CDO, for that matter)" (p. 119). Probing the meaning of various financial subjects allows Ascher also to ask "How can it be... that the social character of risk - that is, the social character of risk taking and risk sharing among speculators - appears to them as it does, as relations between the securities themselves?" (p. 46). This camera obscura view increases speculation and undermines the security of securities, as it were. A central product of financial markets, securities, were once valued not in terms of risk, but as a function of return (p. 41). The distinction between risk and return in this formulation may seem trivial, but the overall effect is to render the ability to be secure as a function of one's relation to capital.

Ascher discloses and elaborates on the value of securities as being rooted in "congealed" risk, which I understand to mean that the social character of the commodities is a mask for the actual generator of value (p. 45). For Marx this is always from labor, in a sense, but Ascher describes this concealment through a different kind of labor, the labor of prediction, which is done, of course, by machines and people. Whereas industrial labor always had a commodity product, now we have financial products. In faithfulness to Marx, Ascher probes the character of the making of financial products. What and who are doing the work to generate them, including mathematical concepts like Beta and algorithms? What are the features of "a new and distinctly uncanny mode of prediction and protection" (p. 24)? What do they reveal and conceal?

Insofar as protection is concerned, however, Ascher engages the reality of the United States ruling class--the holders of capital or those with the best portfolios--who are withdrawing support for public protections and increasingly abandoning individuals to the private system which is in theory available to all, though most people require a loan to access it. Thus, the deep ways that the current incantation of the class system dabbles in the realm of the future, implicates people not so much as laborers, per say, but as debtors and creditors...in their relation to capital. The people and systems deciding what counts as risk and how to interpret it do so within a system of vast inequality, which means that the future is brought about by a small number of actors. Here Ascher again expands on Marx:

What Marx did not say, but what can be presumed, is that a world where people decide together on what is to be produced is also a world where people decide together on what possibilities are to be pursued, what dangers are to be avoided, what risks are worth taking. In such a society, in other words, the means of prediction and protection would also be held 
in common, and the fetishism I have been describing - the fetishism of securities - would also disappear. (p. 59)

Instead, we can read the world we encounter today in part through Securities and Exchange Commission v. Tourre (2012), the significance of which according to Ascher is revealing the secret "that markets are indeed 'made,' and made by people who are inevitably embedded in unequal relations of power" (p. 116). Ascher does not invoke a romantic view of the past when he points to the "erosion of formerly mutualized relations of risk and protection" and "enclosure of the market itself" as features of this new mode of prediction. Rather, he reminds us of Marx's view in volume Three of Capital that bonds are a "claim on future value" and are therefore fictitious capital, though capital was always fictitious to begin with (p. 80).

Ascher's reading of contemporary finance is perceptive and thoughtful. The critical idea that we live in "a historically unique portfolio society in which capital's relation to its own future (and hence everyone's relation to the future) is itself mediated by financial markets" is a significant formulation of what is at stake in the circulation of power/knowledge today (p. 24). Ascher's meditation on the race track betting of his grandfather and his subsequent decision to think finance in those terms rather than as a casino is a smart way to invoke the layers of complexity involved in righting the camera obscura to perceive how things actually work. Marx's Moneybags figure becomes embroiled in this articulation as well, and Ascher convincingly observes that:

Moneybags seems to no longer care whether or not a promise will be kept (or, to put it in the language of French philosophy, whether or not a letter will reach its destination), so long as he thinks he can calculate the probability that the promise will be kept or that some letters will arrive. (p. 79)

The layering of financial products as protection involves computing power and high levels of mathematical competency which conceal "the dense social relations and the peculiar kind of violence that are required for such a portfolio to exist in the first place" (p. 79).

The criminalization of poverty, what Ascher discusses as creating vagabonds, is a part of this violent process which "creates" intense wealth in the financial sector. Not unlike massive and violent changes to Europe 500 years ago we are witnessing a global process "confronting people with a form of insecurity against which they had previously been shielded - or more precisely, a form of insecurity against which they $\{$ we $\}$ had shielded each other collectively" (p. 88). This new insecurity that we face alone as individualized subjects is represented as both alive and dead (zombies), our creation but also us (Frankenstein). In the latter metaphor, the drive to create and control undermines itself, which is a useful observation of the present moment and entirely in line with historical materialism.

Regarding my own thinking on these subjects, Ascher's book raises a lot of questions for me that all come back to Lenin's formulation in "What is to be done?" What kind of strategy emerges if the goal is to seize the mode of prediction and make it available to all, from each according to their ability and to each according to their needs? What are the features of a world where we can, in solidarity with all and through our work, determine the pathways of our future freed from the ceaseless obligation our current debts impose on us? Ascher's project is part of the answer as he draws together critical studies of the sociology of economics and finance, the work of critical accounting, literary theories of finance, and political theory that engages with the economic terms of the present in their most profound forms by exposing their social meanings. Portfolio Society is a gentle reminder that classes are made and that capitalism evolves in ways we must continue to try to understand. 